Journal of Entrepreneur and Entrepreneurship, Vol. 7, No. 2, September 2018, 87-94

ISSN 2302-1802 print / ISSN 2580-9393 online

\title{
CASE STUDY OF FINANCIAL STRATEGY IN THE DEVELOPMENT \& OBSTACLES OF STREET VENDORS IN SURABAYA
}

\author{
Alan Suryawijaya \& Liliana Dewi \\ Universitas Ciputra Surabaya, Surabaya, Indonesia
}

\begin{abstract}
This study aims to find out what factors are hampering the BEST APKLI (Asosisasi Pedagang Kaki Lima Indonesia/Indonesian Food and Drink Street Vendors Association) partnership concept for street food vendors category A in Gubeng Regency Surabaya, Indonesia, The study is classified as a case study. The street vendors were selected based on purposive sampling with related selection based on the accessibility between researchers and the source. The study found that business capital is not an inhibiting factor in the development of MSMEs (micro, small, and medium enterprise).
\end{abstract}

Keywords: business development challenges, business capital, SMEs

\section{INTRODUCTION}

The Indonesian economic condition continues to grow, one of which is influenced by the growth of MSMEs (micro, small and medium enterprise) which are the economic fundamentals in Indonesia. This is proven by the data shown by DEKOP (Departemen Koperasi) (2015-2016), that 53,3\% of Indonesia's GDP (Gross Domestic Product) in 2015-2016 came from MSMEs. In the same year, MSME also shows an increase up to $57 \%$.

The development of MSME and Street Vendors $(P K L)$ is one of the main economic drivers in Indonesia. In addition, MSMSEs also play a role as a solution in Indonesia's economic and social problems, such as: the amount of unemployment, poverty rates, uneven development, economic inequality, etc. (Agustina, 2015). Food vendors itself is a part of MSME. In 2015, Surabaya had over 59,000 MSMEs, of which more than 39,000 of them are street vendors.

\footnotetext{
*Corresponding Author.

e-mail: Ldewi@ciputra.ac.id
}

Street vendors in Indonesia suffer several challenges in developing their businesses. Some basic problems that they face includes marketing, business capital, business development and business competitiveness, and business location (Kuncoro, 2010). In reality, a well-organized street vendor can contribute to tourism, as a culinary tour. A similar statement was also conveyed by Alma (2011) that culinary is an important factor in various types of tourism because food is human basic needs. According to Agustina (2015), there are several types of MSME partnership patterns, namely: capital profit sharing/leasing- land, premises, adoptive companies, franchises, branches, supply chains, upstream-downstream buying other businesses, developing businesses, and organization entrepreneurship.

\section{METHOD}

The study is based on case study, which aims to describe the condition of the object or 
Alan Suryawijaya \& Liliana Dewi / Case Study of Financial Strategy in The Development \& Obstacles of Street Vendors in Surabaya / JEE, Vol. 7, No. 2, September 2018, pp 87-94

the problem in the research. According to Yin (2018), case study is an appropriate strategy to be implemented in a real situation when the main research question is asking about "how" or "why".

As an informant of the research, the subject of this study are street food and drink vendors owners who had been running their business for at least five years and the business sales of at least 700 portions per day (street food and drink vendors category A).

Thus, the informants of this study are Mrs. SUM, Mr. Sujono, Omso, Triyono, and Andreas. All of the informant owns a street food and drink vendors category A, and they are also trying to get a spot in the Gubeng District area, Surabaya, Indonesia.

The data obtained on this study is in the form of qualitative data. According to Kuncoro (2003), qualitative data is a set of data that cannot be measured by numeric scale.

This study is based on primary and secondary data. According to Moleong (2014), primary data source in a qualitative study can be found through words and actions, while the rest are additional data such as documentation and others.

\section{RESULT AND DISCUSSION}

The result of interviews with the informants that discussed their interest in business development as follows:

Ms. Sumarti (Sum) states her statement on the same question as follows:

“...well actually I want to open a new store. I wish I can open one for my husband's sibling rather than only helping me here..."
“...Yes, I wish so too. But who wants to be like that, do you have one?..."

“...the seller also have benefits. But only if you want. Gets the capital money and share the profits, of course I want it. It is very good. If so, I want to invite other people ...."

Analysis based on the respondents' answers as follows: High interest in developing her business, but still unsure whether there is an opportunity. High interest in partnership and/or opening a new branch.

Mr. Sujono (PSJ) states her statement on the same question as follows:

" ...No, Mr. Right now, I have a hard time to control my business. If I open a new one, there will be no one to takes care of the new branch...."

"...I want to do it, but the system is not ready yet, Mr. The one who will take care of the business, the income, then how about if my products don't sell well? Who wants to give me the capital money...."

"... How about the money? I actually want to do similar thing, but I'm afraid that the investor lies to me, only wants my recipe then leave me alone...."

“... I really want to open a branch, but there is nobody to help me. But I don't know, if it's your program, then I'll think about it...."

Analysis based on the respondents' answers as follows: Have a desire to open a branch/develop his business, but have a higher amount of worries. A small chance of making changes to his business: low level of trust to other people or may have a trauma. This can 
also be seen by his behavior in working alone without any help. However, there is a desire to open a branch or to grow his business.

Mr. Omso (POS) states her statement on the same question as follows:

"...For me, Mr, all is the same. The most important thing is I can sell something...."

“...Well ideally its good. But who will control the businesses?..."

“...I asked my child to sell my product, my younger sibling, my wife's sibling too...."

Analysis based on the respondents' answers as follows: Open a branch/make the business name well-known. The most important thing is that he can sell the products well. There is little concern regarding financial transparency. POS actually already open a branch, but the brunch is still controlled by his younger siblings and his child.

Mr. Triyono (MTR) states her statement on the same question as follows:

“...Not yet, Mr. Still cannot set the business. Right now, I am still figuring things out...."

“...How about the profit, how to count and divide it?..."

Analysis based on the respondents' answers as follows: There is a desire to grow, however he is still afraid of the system to open a new branch and the supervision or control. Mr. Andreas (PAN) states her statement on the same question as follows:

“...I wish my wife can open a branch in Rungkut area...."
“...Yes, if I don't want to bear the risk, then I choose to have a partnership...."

Analysis based on the respondents' answers as follows: Already have a plan to open a branch and prefers to open a branch by partnering with a funding program.

The result of interviews with the Informants regarding business capital as follows:

Ms. Sumarti (Sum) states her statement on the same question as follows:

“...no Mr., I am not able to pay for BPR. Even my motorbike is paid through installment. There was somebody who offers be my partner, but the location is not suitable. I don't want to buy the produces, but then nobody wants to buy my food, hence I cannot have enough capital, Mr....”

Analysis based on the respondents' answers as follows: Small capital, so she can provide her own business capital. Do not wish to borrow money from $B P R$ for fear of high interest. $B P R$ requirements are too much. Loans are only for vehicle credits.

Mr. Sujono (PSJ) states her statement on the same question as follows:

”... I just made everything by myself. In the village there are many woods from my neighbors that are not used, so I took it. Also, my in-law's house is near a furniture factory, so I asked for unused woods. I cut it and paint it by myself...."

“...Well, now I only rely on the mung beans, Mr. These 4 full pans only cost me around 1 million rupiah...."

“...No Mr., I don't borrow anybody's money, I use my own saving from previ- 
Alan Suryawijaya \& Liliana Dewi / Case Study of Financial Strategy in The Development \& Obstacles of Street Vendors in Surabaya / JEE, Vol. 7, No. 2, September 2018, pp 87-94

ous work and just borrow a little from my wife...”

“...We do not like to loan from the bank. We are afraid...."

Analysis based on the respondents' answers as follows: Informants doesn't like to loan money from the banks. Business capital will be from his own savings. Not prepared to loan money from the bank. The business capital is not too much.

Mr. Omso (POS) states her statement on the same question as follows:

"...Already, Mr., my friends were complaining after they go there...”

“...I used to work in a palm oil plantation in Kalimantan, Mr. Then I also learn how to cook in a restaurant. I also used to sell food similar to this when I was in Kalimantan. Then I go back to Surabaya, my wife wants to go back home because we are pregnant with our second child...."

Analysis based on the respondents' answers as follows: Do not wish to loan money from BPR due to the high interest rate. Capital money comes from savings from previous sales. Mr. Triyono (MTR) states her statement on the same question as follows:

“...Never, Mr.” “...My own capita, Mr. I used to borrow money from my in-laws. But now, no more borrowing money from others. Well, Alhamdulillah, we have enough now...."

Analysis based on the respondents' answers as follows: Have never used BPR. He loans money from his in-law as his first business capital.
Mr. Andreas (PAN) states her statement on the same question as follows:

“...This is my in-laws' legacy. They already have this since my wife's grandmother. They have sold food here since the 60s. But my in-laws said. They used to only sell mung beans. Then my mother in-law, added this Padang menu. Because my mother in-law is from Lampung. Her foods are all delicious...."

Analysis based on the respondents' answers as follows: Business capital has been inherited from his in-laws. He just continues their business. Never loan money from the bank.

Other than the result of the interview, the researchers also conducted an assessment to determine the value of the financial and customer aspects. This can be seen from the result of the researcher's observation in regard to the assessment notes as follows:

Informant SUM

- Estimated average turnover according to the Informant's husband per day $= \pm 6$ million

- Estimated average capital per day $= \pm 3$ million

- Estimated average net profit $= \pm 2$ million

- Estimated average of customer per day = \pm 350 customers

According to the information above, it can be seen that SUM has a very good potential to multiply her business. Seen from the amount of profit per day, it can be seen that the business is quite profitable. If in one day Informant $\mathrm{A}$ can gain a net profit of 2 million rupiah, then in 1 year with 280 working day, the estimated annual profit is 560 million rupiah. Let say, $50 \%$ of the profits is saved for business re- 
serves, $20 \%$ is for preparation of opening a new branch, and 30\% is used for daily needs. Hence, 3 years is actually a sufficient time to get a selffinancing to open a new branch. It will be better if she opens a branch in a cleaner and more crowded area, such as a food court, employee canteen or a mall; it will bring a special attraction to the business.

\section{Informant PSJ}

- Estimated average turnover according to the Informant's wife per day $= \pm 4$ million

- Estimated average capital per day $= \pm 2$ million

- Estimated average net profit $= \pm 1.5$ million

- Estimated average of customer per day $=$ \pm 250 customers

From the information above, it appears that PSJ has the potential to develop his business into a larger business in the future. Although he only sells food with the same basic ingredients, mung beans, PSJ is able to serve the mung beans into different models and drink variants. His creative ideas and high level of flavors is proven by the number of devotees on each day. Every day, PSJ can sell up to 2-3 pans of mung beans. In addition, the informant's turnover is also quite large, which is around 3 million per day. The researchers are optimistic that if the business is developed and can open a new branch in café, food court or mall, PSJ can have a successful and a busy business in the future.

\section{Informant POS}

- Estimated average turnover according to the Informant's wife per day $= \pm 2.5$ million

- Estimated average capital per day $= \pm 0.5$ million

- Estimated average net profit $= \pm 1.5$ million
- Estimated average of customer per day $=$ \pm 400 customers

Based on the researchers' observation, it appears that with a small capital can generate a good income. In addition, to open a new branch, POS only needs to prepare a motorbike, aluminum storefront wagons, cooking equipment, consumables and raw materials. Indeed, POS has already multiplied its business.

\section{Informant MTR}

- Estimated average turnover according to the Informant's wife per day $= \pm 12$ million

- Estimated average capital per day $= \pm 6$ million

- Estimated average net profit $= \pm 5$ million

- Estimated average of customer per day = \pm 500 customers

The data shows a high level of income from MTR's business; it is almost hit the limit of MSME category turnover, which is 4.8 billion per year. It appears that the informant has obtain a large number of customers too. In addition, even though POS has moved his business twice in different places, the business still attracts a high number of customers and hence a high level of turnover. If MTR decided to open a new branch in other area, MTR actually has a high potential to success. MTR should no longer worried about the issue of capital to open a new branch.

\section{Informant PAN}

- Estimated average turnover according to the Informant's wife per day $= \pm 4$ million

- Estimated average capital per day $= \pm 2$ million

- Estimated average net profit $= \pm 1.5$ million

- Estimated average of customer per day = \pm 250 customers 
Capital constraints in developing the informants' Business as follows:

SUM say "...no $M r$, I am not able to pay for BPR. Even my motorbike is paid through installment..." Result of Researcher's Observation are Average of daily capital of raw materials and consumables $= \pm 4$ million. Average of daily turnover $= \pm 7$ million. Average of daily net profit $= \pm 2$ million. High daily profits, high and stable turnover, small capital, fast capital turnover. The possibility of money being set aside as a reserve fund is high.

PSJ say: “...No Mr., I don't borrow anybody's money, I use my own saving from previous work and just borrow a little from my wife...."

"...Yes, this is actually my mother inlaw's business. But she said she is tired already, so she asked my wife to continue the business. However, my wife didn't want to. She prefers to take care of her baker. So, I step in and continue my inlaw's business, I don't want the business to go to waste. Also, my wife's bakery is very popular already....

"Result of Researcher's Observation are Average of daily capital of raw materials and consumables $= \pm 2$ million. Average of daily turnover $= \pm 7$ million. Average of daily net profit $= \pm 2$ million. High daily profits, high and stable turnover, small capital, fast capital turnover. The possibility of money being set aside as a reserve fund is high.

POS say "...Those location in the corner, they ask to share the profits. We don't need to rent the place but only divide the profits. But nobody wants to be there, $M r$. Most likely, we need to pay more when we share our profits rather than renting a spot...."

"...Already, Mr., my friends were complaining after they go there...."

Result of Researcher's Observation are Average of daily capital of raw materials and consumables $= \pm 0.5$ million. Average of daily turnover $= \pm 2.5$ million. Average of daily net profit $= \pm 1.5$ million. High daily profits, high and stable turnover, small capital, fast capital turnover. The possibility of money being set aside as a reserve fund is high.

MTR say "...It is better this way, Mr. No need a big capital...."

"My own capital, Mr. At first, I borrow money from my in-laws ...."

"...I pay it by cash. I just save my money first...."

"...next year if the fortune is with me, I want to get an Ertiga, Mr...."

Result of Researcher's Observation are Average of daily capital of raw materials and consumables $=6$ million. Average of daily turnover $= \pm 12$ million. Average of daily net profit $= \pm 5$ million. High daily profits, high and stable turnover, small capital, fast capital turnover. The possibility of money being set aside as a reserve fund is high, can last for at least 5 years.

PAN say “...This is my in-laws' legacy. They already have this since my wife's grandmother. They have sold food here since the 60s..."”...No, Mr. I want to loan money from the bank, they said I don't have the documents. I want to take KUR (People's Business Credit) but I am not allowed to...." 
Result of Researcher's Observation are Average of daily capital of raw materials and consumables $= \pm 4$ million. Average of daily turnover $= \pm 10$ million. Average of daily net profit $= \pm 5$ million. High daily profits, high and stable turnover, small capital, fast capital turnover. The possibility of money being set aside as a reserve fund is high, can last for at least 5 years.

According to Agustina (2015), MSMEs and street food vendors have several challenges that they face before they are able to develop their business, such as uncertain income, losses due to loss of investment capital, hard work and longer time to achieve a prosper life, and their quality of life remains low despite their steady efforts. Tanjung (2017) there are several alternative to get an initial capital to develop a business, including: collecting reserve funds from profits (self-funding), relying on loans from banks, relying on cooperative capital or local BPR, utilizing CSR facilities and revolving funds, utilizing zakat and infaq funds, partnerships, and franchises. Suci (2017), weaknesses faced by MSME entrepreneurs in improving business capability are very complex and include a variety of indicators which are interrelated with one another; lack of capital both in number and source, lack of managerial ability and operating skills in organizing and limited marketing.

The use of additional income to strengthen operations was also in lime with the finding of Acho-chi (2002).

The biggest consideration of most informants in regard to opening a new branch is due to the inability to have enough capital. The informants have not been able to aside and save a portion of their daily profits to carry their business development plans. On the other hand, the researchers also draw a conclusion that MSMEs and street vendors are always identical to the non-bankable sector, because they do not have a proper financial report and unable to arrange financial planning properly.

\section{REFERENCES}

Acho Chi, C. 2002. The mobile street food service practice in the urban economy of Kumba, Cameroon. Singapore Journal of Tropical Geography, 23(2), 131-148.

Agustina, T.S. 2015. Kewirausahaan UMKM di Indonesia. Jakarta: Mitra Wacana Media.

Alma, B. 2011. Kewirausahaan. Bandung: Alfabeta.

Kuncoro, M. 2003. Metode Riset untuk Bisnis dan Ekonomi. Jakarta: Erlangga.

Kuncoro, M. 2010. Dasar-Dasar Ekonomika Pembangunan. Yogyakarta: UPP STIM YKPN.

Moleong, L.J. 2014. Metodologi Penelitian Kualitatif. Bandung: PT Remaja Rosdakarya.

Suci, Y.R. 2017. Perkembangan UMKM (Usaha Mikro Kecil dan Menengah) di Indonesia. Cano Ekonomos, 6(1), 51-58.

Tanjung, M.A. 2017. Koperasi dan UMKM sebagai Fondasi Perekonomian Indonesia. Jakarta: Erlangga.

Yin, R.K. 2018. Case Study Research and Applications: Design and Methods (6 ${ }^{\text {th }}$ ed.) Thousand Oaks, CA: SAGE. 
Alan Suryawijaya \& Liliana Dewi / Case Study of Financial Strategy in The Development \& Obstacles of Street Vendors in Surabaya / JEE, Vol. 7, No. 2, September 2018, pp 87-94 